\title{
eLyra
}

REVISTA DA REDE INTERNACIONAL LYRACOMPOETICS

\section{Mário Cesariny, artista-crítico}

\author{
Maria Silva Prado Lessa \\ Universidade Federal do Rio de Janeiro
}

Resumo: Os encontros com o fazer artístico alheio são um dos motivos centrais da poética de Mário Cesariny tanto em seu trabalho como pintor, escultor e desenhista quanto em sua escrita. No livro As Mãos na Água, a Cabeça no Mar, a voz do poeta-Cesariny parece dar lugar a uma dicção de um artista que põe diante dos leitores seu ateliê, sua oficina de trabalho, apresentando o processo criativo como um aprendizado e um encontro com o outro. A pluralidade de diálogos e a multiplicidade de paródias, de citações, de menções e de nomeações fazem com que o leitor dedicado a sua obra passe a duvidar da posição autoral, buscando em cada poema, tela, objeto e tradução aquilo que é genuinamente cesarinyano e o que provém de outro artista. Diante do poema traduzido "Os passeios", publicado em As Mãos na Água [...], o leitor atento às misturas de discursos se interroga a respeito da autoria do texto: Kandinsky ou Cesariny?

Palavras-chave: Mário Cesariny, intertextualidade, autoria

Abstract: One of the central motives of Mário Cesariny's poetic is the encounter with different artists' works as we can see in his paintings, sculptures, drawings and writings. In the book As Mãos na Água, a Cabeça no Mar [Hands On Water, Head In The Sea], the voice of the poet Cesariny seems to give way to a more open speech by putting before the readers his workroom, presenting the creative process as a learning and an encounter with the other. The plurality of dialogues and the multiplicity of parodies, citations and nominal mentions make the reader dedicated to his work doubt the author's position, seeking in each poem, screen, object and translation what is genuinely from Cesariny and that which comes from another artist. Reading the 
translated poem "Os passeios" ["The walks"], published in As Mãos na Água [...], the reader attentive to the mixtures of speeches questions himself about the authorship of the text: Kandinsky or Cesariny?

Keywords: Mário Cesariny, intertextuality, authorship

Em 1970, Mário Cesariny escrevia, acerca da obra da artista plástica Maria Helena Vieira da Silva, que "a sua pintura obriga ao silêncio. Como falar sob a sua pintura?" (1985: 182). Nessas palavras, o artista de ofício múltiplo manifesta algo da sua condição como leitor e espectador de arte, expressando um questionamento similar àquele suscitado pela transposição ecfrástica que se apresenta no conflito entre escrita e artes visuais. Em simultâneo, as telas de Vieira da Silva calam e impossibilitam a elaboração simbólica por aquele que com elas se encontra e provocam a urgência da formulação de uma nova língua, a invenção de um novo código: como falar?

O encontro com o fazer artístico alheio é um dos motivos centrais da poética do surrealista português - tanto em seu trabalho como pintor e escultor, quanto em sua prática escrita. Lançando perguntas às obras de outros e à sua própria, Cesariny desenvolve uma dicção marcadamente metapoética e autorreflexiva, apresentando "artes poéticas" que, ao mesmo tempo em que defendem um modo próprio de composição, são, também, a prática em ato de um exercício de leitura e de diálogo.

Assim, ler as referências a outros artistas em sua obra implica, fundamentalmente, uma investigação que leve em consideração não apenas uma recolha de suas influências, mas que perceba que esses diálogos são a própria base da sua poética. Não devem, portanto, ser lidos apenas como componentes temáticos, mas como fatores estruturantes de um trabalho que espera do leitor nada menos do que um encontro intensamente amoroso: a um tempo "único" (porque individual) e "múltiplo" (porque sempre vário, contra qualquer leitura totalitária e totalizante). 
Pode-se dizer, então, que as relações intertextuais que se estabelecem são declarações duma estética e duma ética, na defesa constante da necessidade de pôr-se à espera do outro, de o encontrar e o sonhar, como se lê em "poema":

\author{
em todas as ruas te encontro \\ em todas as ruas te perco \\ conheço tão bem o teu corpo \\ sonhei tanto a tua figura \\ $[\ldots]$ \\ que o meu corpo se transfigura \\ e toca o seu próprio elemento \\ num corpo que já não é seu \\ num rio que desapareceu \\ onde um braço teu me procura. (Cesariny 2004: 30)
}

\title{
Ler, ver e fazer
}

Grande propagador, defensor e praticante do surrealismo, Mário Cesariny atrela sua produção inicial, sob o signo da "dissolução dos opostos", ao que André Breton, Louis Aragon, Paul Éluard, Robert Desnos e cia. publicaram na França a partir da década de 1920, retomando, diversas vezes, práticas por eles desenvolvidas. O texto "Final de um manifesto", escrito em 1949 - ainda nos primórdios do surrealismo português -, apresenta um dos protocolos inaugurais de filiação dos signatários lisboetas ao movimento e uma declaração de vinculação a determinados artistas e obras:

A (nossa) posição surrealista decorre:

dos "Manifestos do Surrealismo" na edição Sagittaire, 1947;

dos "Prolegómenos a Um Terceiro Manifesto do Surrealismo ou Não", da mesma edição;

das declarações do Grupo em França em 1947 e 1948: "Rupture Inaugurale” e “À Bas les Glapisseurs de Dieu";

das comunicações de 6 de maio deste ano, no Jardim Universitário de Belas-Artes, de Lisboa; de uma vida de imaginação;

de um certo poder de repulsa e de obstinação;

da vida particular e pública de cada um dos signatários; 
da obra colectiva de Segismund Freud, Mário de Sá-Carneiro, Arthur Rimbaud, Guillaume Apollinaire, Antonin Artaud, Heraclito, Hermes, Vladimir Ilitch Novalis - a loucura, a sabedoria, a magia, a poesia; das alucinações de Raul Brandão, Gomes Leal e Ângelo de Lima; do assassino de Fernando Pessoa: Ricardo Reis; do fator Cheval; dos picto-poemas de Brauner, Matta, Herold, Ernst, Duchamp, etc.

À palavra de Rimbaud: "La vraie vie est absente", juntamos o axioma mágico da grande conspiração contra a permanência das coisas, guilhotina de amor sobre a infantilidade dos gestos de repouso: "No círculo da sua acção, todo o verbo cria o que afirma".

Mário Cesariny, 1949. (Cesariny 1966: 155-156)

Cesariny parece retomar, nesse texto, algo que havia sido feito no Manifesto do Surrealismo de 1924, no qual André Breton afirma que "um grande número de poetas poderia passar como sendo surrealistas" (Breton s.d.: 192), destacando de diversos autores aquilo que neles interessa à revolução poética que então propunha. A longa lista de nomes aponta muitas influências, mostrando que o movimento é "decorrente" de uma herança infinita, fato que se manifesta pelo "Etc." posto ao final:

Swift é surrealista na maldade.

Sade é surrealista no sadismo.

Chateaubriand é surrealista no exotismo.

Constant é surrealista em política.

Hugo é surrealista quando não é tolo.

Desbordes-Valmore é surrealista em amor.

Bertrand é surrealista no passado.

Rabbe é surrealista na morte.

Poe é surrealista na aventura.

Baudelaire é surrealista na moral.

Rimbaud é surrealista na prática da vida e alhures.

Mallarmé é surrealista na confiança.

$[\ldots]$

Etc. (Breton s.d.: 192) 
O inventário de influências apontadas pelos dois grupos surrealistas pode ser compreendido em termos do que defende Octavio Paz em "A Tradição da Ruptura" para pensar a existência de uma "tradição moderna da poesia". Em seu ensaio, o crítico mexicano propõe a modernidade como "uma tradição polêmica que desaloja a tradição imperante, seja ela qual for" (Paz 2013: 15). Como negação do passado, o moderno, "cada vez que aparece, funda sua própria tradição" (idem: 16). Nesse sentido, a ruptura torna possível não apenas recuperar do passado ou de culturas distantes tradições diferentes, apagando "as oposições entre o antigo e o contemporâneo e entre o distante e o próximo" (idem: 18), mas permite uma leitura nova da própria tradição. O fim que se declara na modernidade, portanto, possibilita uma relação com o tempo e com o espaço diferente a cada vez em que se anuncia a ruptura, desfazendo a linearidade temporal que liga passado, presente e futuro para anunciar a (quase surrealista) dissolução dos opostos, num "tempo arquetípico" (Paz 1982: 228) sempre presente, em que o passado se faz novo. Para Paz, provocaria uma "[d]upla e vertiginosa sensação: o que acabou de acontecer já pertence ao mundo do imensamente distante e, ao mesmo tempo, a antiguidade milenar está infinitamente perto" (Paz 2013: 19).

Nesse sentido, ao apontar em que "é surrealista" cada um dos artistas elencados, Breton não apenas retoma certa "linhagem" poética para com ela identificar o surrealismo, mas funda um novo modo de a ler. Por meio dessa operação, a atitude surrealista passa a agir sobre o passado, alterando o significado das obras alheias em termos dos pontos de articulação e de organização que propõe. Se a lista dos franceses tem como consequência uma ação retroativa, na reelaboração dos sentidos de obras passadas, a de Mário Cesariny aponta para uma recolha de diversos pontos de partida, numa eleição de sua ascendência artística. Assim, ao caracterizar sua atividade artística como "decorrente" - ou consequente - das produções de outros artistas e de sua própria "vida de imaginação", assinala e cria sua própria tradição. Não se trata de assumir uma posição originária, mas de admitir uma originalidade, já que defende que os artistas e obras listados são postos a se encontrar de maneiras únicas na vida particular de cada um, fundando múltiplos pontos de partida.

A ruptura com a perspectiva de um desenrolar linear do tempo se dá, portanto, por meio da explicitação de um ato de leitura no momento em que se escreve, implicando uma 
construção em abismo - sucessão e retomada infinita de outros tempos e vozes presentificadas pelo trabalho de leitura-e-escrita empreendido pelo autor. Em "Final de um Manifesto", Cesariny declara sua condição de leitor formado por uma herança poética e a de escritor que funda essa mesma tradição. Ainda que tenha surgido como um texto coletivo dos surrealistas portugueses, o panfleto, ao defender a possibilidade de haver um contato íntimo e particular de cada um dos signatários com as obras e figuras que compartilham como influências, não tem como intenção a fundação de uma poética coletiva, mas individual.

O gesto de trazer ao seu próprio trabalho o diálogo com diferentes artistas, culturas, tempos e lugares, fazendo com que se encontrem por um ofício artístico único, pode ser considerado uma marca característica da poética de Cesariny, posto que as influências inventariadas em "Final de um Manifesto" serão retomadas não apenas em seus textos de intervenção, mas em muitos momentos de sua obra, emergindo, por vezes, como o tema central das composições. No recém-publicado volume Poesia (2017), recolha de quase toda a produção lírica cesarinyana, pode-se constatar que, de um universo de 251 poemas ${ }^{1}$ reunidos por Perfecto Cuadrado, 42 textos trazem, em seus títulos apenas, homenagens, referências e dedicatórias nominais a outros artistas, como "Homenagem a Cesário Verde", "O teatro da crueldade: Antonin Artaud", "À Victor Brauner", “À André Breton" e "Passagem de Rimbaud".

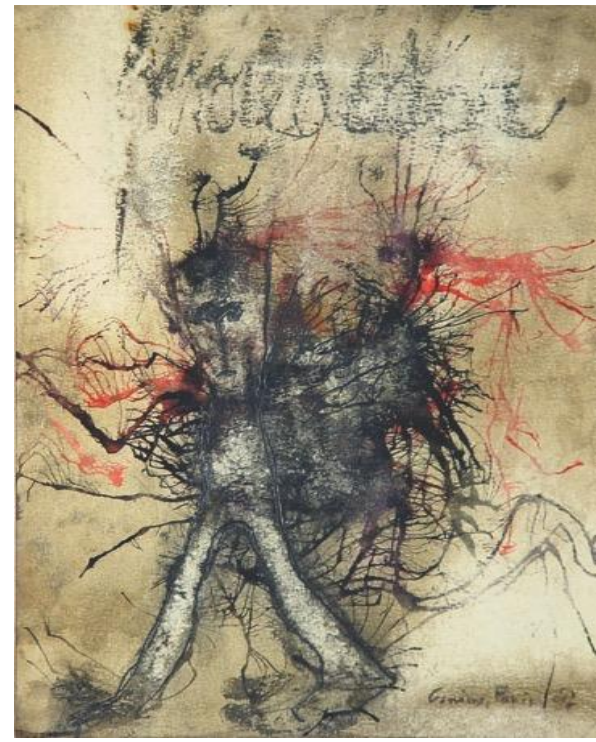

Figura 1 - Maldoror, Mário Cesariny (1947), tinta da china sobre papel colado em platex, $29 \times 24 \mathrm{~cm}$ 
O incessante diálogo com outros artistas foi travado, igualmente, em inúmeras telas, objetos assistidos, esculturas e desenhos como, por exemplo, Maldoror (1947) (Figura 1), em homenagem a Lautréamont, e Fernando Pessoa Ocultista (produzido entre 1957 e 1981) (Figura 2). Para além de se manifestarem nas produções lírica e plástica, as interlocuções se destacam em suas traduções de Rimbaud, de Artaud e de Breton, e em seus estudos da obra de Vieira da Silva e de Arpad Szenes - especialmente representados no livro Vieira da Silva / Arpad Szenes ou O Castelo Surrealista (1984) - e da literatura de cordel portuguesa - tendo publicado Horta de Literatura de Cordel, em 1983. Cesariny se distingue, também, como compilador da produção surrealista e abjeccionista, campo no qual se pode perceber, novamente, sua intensa atividade de leitura.

Para além dos títulos, as referências a outros poetas, músicos e artistas visuais podem ser constatadas no corpo de seus poemas, frequentemente permeados por menções a composições alheias, colagens e transformações destas, formando uma intrincada rede de correspondências e comunicações. O trabalho constante de leitura que assim se declara em sua obra faz com que nela se imprima um discurso crítico voltado seja sobre o trabalho de outros, seja sobre o seu próprio.

No poema " $X$ " de Discurso sobre a Reabilitação do Real Quotidiano (1956), é possível perceber a maneira como Cesariny produz um emaranhado de citações e de referências, ao retomar uma expressão do poema "Tenho dó das estrelas", de Fernando Pessoa, mencionar Rainer Maria Rilke e Pablo Picasso e ao converter Lautréamont em interlocutor, posto a dialogar com o eu lírico:

falta por aqui uma grande razão

uma razão que não seja só uma palavra

$[\ldots]$

faltas tu faltas tu

falta que te completem

ou destruam

não da maneira rilkeana vigilante mortal solícita e obrigada

$[\ldots]$ 
falta uma grande realmente razão

apenas entrevista durante as negociações

oclusa na operação do fuzilamento cantante

rodoviária na chama dos esforços hercúleos

morta no corpo a corpo do ismo contra ismo

$[\ldots]$

falta, ó Lautréamont, não só que todo figo coma seu burro

mas que todos os burros se comam a si mesmos

[...]

isso eu o espero

e o faço

junto à imagem da

criança morta

depois que Pablo Picasso devorou o seu figo

sobre o cadáver dela

e longas filas de bandeiras esperam

devorar Picasso

que é perto da criança, ao lado da boca minha. (Cesariny 2008: 85-86)

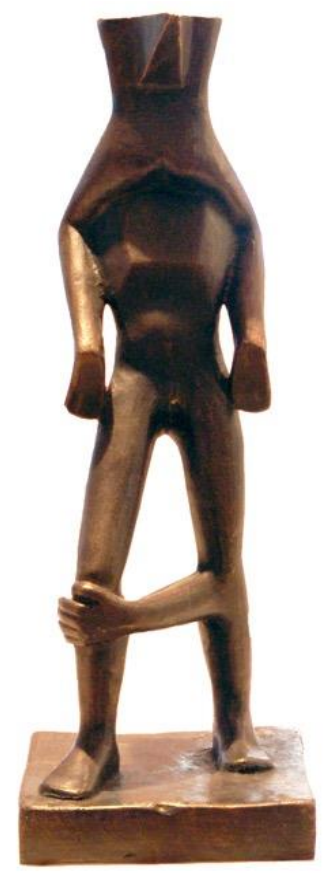

Figura 2 - Fernando Pessoa Ocultista, Mário Cesariny, $1957 / 1981$ 
O poema apresenta ao menos três formas de diálogo com outros artistas em simultâneo. A primeira se encontra na retomada de alguns versos de Pessoa, a qual constituirá a estrutura central do poema:

\author{
Não haverá, enfim, \\ Para as coisas que são \\ Não a morte, mas sim \\ Uma outra espécie de fim, \\ Ou uma grande razão - \\ Qualquer coisa assim \\ Como um perdão? (Pessoa 1985: 149)
}

A citação instala um diálogo com esse poeta não apenas ao nível do tema, como também da estrutura sobre a qual a composição se apoia, uma vez que a "falta" de "uma grande razão" será repetida em diversos momentos. Um segundo modo de diálogo se encontra na menção a Rilke e em sua passagem de substantivo a adjetivo (a "maneira rilkeana") que revela uma interpretação da obra, posto que as expressões que se seguem operam como uma explicação do que é a "maneira rilkeana": "vigilante mortal solícita e obrigada". De maneira similar, refere-se a Picasso tanto como homem ("depois que Pablo Picasso devorou seu figo") quanto como metonímia de sua obra, uma vez que "Picasso" pode ser lido como equivalente a "uma tela de Picasso", pois os versos "longas filas de bandeiras esperam / devorar Picasso" o transfiguram em mais um objeto a ser devorado, como uma tela em um museu - apresentando, aí, uma possível crítica à transformação da arte em mercadoria e em uma experiência consumível. Ainda a nível de referência, os "ismos" retomados pelo eu lírico emergem tanto em sua dimensão político-econômica - o capitalismo, o fascismo, o socialismo, o comunismo - quanto artística, na explosão dos "ismos" observada desde finais do século XIX - já no século XX português, o modernismo de Orpheu, o futurismo, o presencismo, o neorrealismo, o surrealismo, por exemplo -, fazendo com que os dois campos de discurso sejam igualados por sua capacidade de "matar" a "grande realmente razão" no "corpo a corpo" ideológico. A terceira forma de diálogo toma uma dimensão quase literal, quando se observa que Lautréamont é convertido em interlocutor do eu lírico cesarinyano por meio do uso de um vocativo que presentifica uma 
das mais importantes influências dos surrealistas franceses e portugueses na cena do poema. Com os diferentes modos de se pôr em diálogo com outros artistas, Cesariny oferece ao seu leitor o convite a um longo aprendizado de poesia e arte, numa mistura indestrinçável do exercício artístico com o discurso crítico sobre a obra alheia e a sua própria.

Um dos exemplos mais marcantes da vinculação entre um trabalho permanentemente citacional e uma prática crítica por ele desenvolvida é o livro O Virgem Negra: Fernando Pessoa Explicado às Criancinhas Naturais e Estrangeiras por M.C.V. (1989). Compondo uma grande paródia da obra pessoana, faz um exercício de corte e montagem de poemas e cartas do ortônimo e dos heterônimos, mesclando-os a seus próprios versos. Em "Fernando Pessoa Revisited - Uma leitura de O Virgem Negra, de Mário Cesariny", Julia Gomes assinala que

é válido advertir [que] não há somente textos poéticos em que fica clara a paródia [...], ou aqueles em que Cesariny realiza uma cópia ipsis litteris dos originais pessoanos [...]. Com efeito, apontamos outras possibilidades de construção: há poemas que funcionam como um comentário satírico de citações pessoanas, um que consiste numa tradução nada literal de um texto do autor de Mensagem, e ainda alguns que são criações inteiramente cesarinianas (cujo eu lírico é, na maioria das vezes, o próprio Pessoa). (Gomes 2016: 72)

Cesariny opera, portanto, uma reorganização - ou mesmo uma desorganização - da poética pessoana de acordo com sua própria atividade de leitura, criando uma relação a tal ponto intrincada com a escrita de Pessoa que, por vezes, o leitor de $O$ Virgem Negra não sabe ao certo qual é o autor dos versos que lê, confundindo o hipotexto pessoano e o hipertexto cesarinyano. Para conseguir transitar pelos poemas, é preciso pôr em prática, também, uma atividade de rememoração da poesia de Pessoa.

\section{Ut critica poesis}

Publicado em 1985, o livro As Mãos na Água, a Cabeça no Mar representa mais fortemente o veio crítico de Cesariny. Trata-se de uma recolha de cartas, traduções, ensaios e textos críticos sobre arte portuguesa e estrangeira, escritos e publicados entre os anos de 1950 e 1977. O volume ocupa lugar fundamental em sua obra, sendo frequentemente citado 
por estudiosos com o intuito de esclarecer ou ilustrar o desenvolvimento de sua poética, uma vez que tanto a seleção dos diversos artistas aos quais dedica os escritos quanto a reprodução de textos de intervenção e de cartas permitem uma leitura de alguns motivos que se repetem em sua trajetória, ao reverberarem os diálogos centrais que atravessam poemas e demais produções. A voz do poeta-Cesariny, assim, parece dar lugar a uma dicção de um artista que põe diante dos leitores seu ateliê, sua oficina de trabalho, no qual o processo criativo se mostra como aprendizado e encontro com o outro.

O índice do livro é organizado por artista e por tema, apresentando pequenos dados a respeito do contexto original das publicações de cada escrito, como data, local e periódico em que foram editadas. Sob o subtítulo "Vieira da Silva", por exemplo, encontram-se cinco ensaios publicados entre 1952 e 1970 cujo tema principal é a obra da artista plástica e a relação que Cesariny com ela estabeleceu. Já sob "André Breton", há dois textos a respeito do surrealismo que muito contribuem para a compreensão da leitura que fez do movimento que integrou, praticou e divulgou ao longo dos anos. Entre outras seções, não espanta ao leitor a existência de uma dedicada a Vasily Kandinsky, sob a qual há um único texto, intitulado "Os passeios" e em cuja legenda se lê: “'Os Passeios', poema. Primeira publicação provavelmente no livro 'Ressonâncias', editado em Munique em 1912. Jornal de Letras e artes, Abril 1968" (Cesariny 1985: 10).

A pluralidade de diálogos e a multiplicidade de paródias, de citações, de menções e de nomeações fazem com que o leitor dedicado a sua obra passe a duvidar da posição autoral, buscando em cada poema, tela, objeto e tradução aquilo que é genuinamente cesarinyano e o que provém de outro artista. Assim, querendo investigar o processo de tradução de Cesariny, e para que possa ler, de fato, o livro de influências e diálogos que é As Mãos na Água [...], o leitor deve fazer o que o pede, constantemente, a obra tão intertextual quanto semiplagiária de Cesariny: deve buscar o livro de Kandinsky, pois, como já ensinara Manuel Gusmão em leitura do poema "Homenagem a Cesário Verde", "se o leitor não cumpre o que dele se espera não poderá ler, nos vários sentidos do verbo de acção que ler é, o poema e, neste caso, não há qualquer abuso em supor-se que o leitor quer ler o poema de Cesariny" (Gusmão 2010: 389). 
O livro Klänge [Ressonâncias], de Vasily Kandinsky, é composto de 56 xilogravuras e 38 poemas em prosa em alemão. Produzido nos anos em que o artista viveu em Munique, teve sua tiragem limitada a 345 cópias e nunca foi reeditado em sua inteireza, até a publicação com a reprodução de todas as gravuras acompanhadas da tradução dos poemas para o inglês, em 1981. Para a tradutora Elisabeth R. Napier, o livro expressa a mudança da representação objetiva para a abstração, que se passava na obra de Kandinsky à época, e uma maior atenção à transfiguração contínua do mundo por meio da

experimentation with the construction of words and his attention to modes of repetition and variation of dialogues and chants. These lexical and compositional procedures are augmented by patterns of narrative in the poetry which move from situations of stasis to those of ongoing process. (Napier 1981: 3)

["experimentação com a construção de palavras e sua atenção aos modos de repetição e variação em diálogos e cantos. Tais procedimentos lexicais e composicionais são aumentados por meio de padrões narrativos na poesia, os quais fazem com que situações estáticas passem para outras de processo contínuo"]. ${ }^{2}$

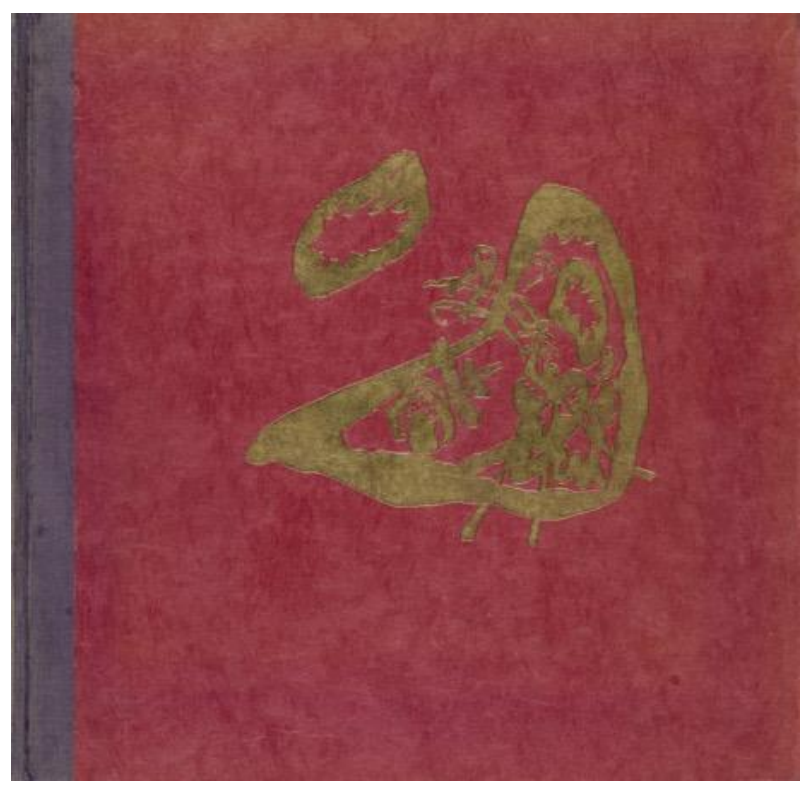

Figura 3 - Capa de Klänge, Vasily Kandinsky (1912)

A combinação entre texto, som e imagem na obra do artista russo resgatada por Mário Cesariny abre um caminho investigativo voltado para as possibilidades de se estabelecer um paralelo identitário entre os dois poetas-pintores que ambos são. Isto é, se o 
surrealista português elege Kandinsky para integrar o seleto cânone que apresenta em As Mãos na Água [...], se o aponta como constituinte de sua própria poética, a primeira hipótese de leitura do diálogo se dá pela via do duplo (ou múltiplo) ofício que foi o desses artistas da imagem e da palavra: Kandinsky e Cesariny, artistas plásticos, poetas, ensaístas e críticos. A tradução e a inclusão do poema no livro de ensaios assinalam, assim, a importância que ocupa na formação de Cesariny o artista russo e seu poema, "Os passeios".

Neste, um narrador descreve figuras de uma cena, conferindo a uma tela a dinâmica de uma narração, valorizando o uso repetido de certos adjetivos que dão ao poema um tom ingênuo, reproduzindo algo que Napier sublinha como "Kandinsky's awareness of the primitive (and here notably childlike) attraction of pure reiteration" ["consciência de Kandinsky acerca da atração primitiva (e aqui notadamente infantil) pela pura reiteração"] (Napier 1981: 3):

Já viram aquele grande prédio que está na extrema periferia daquele grande campo amarelo dourado? Então também já viram a criada que todos os dias passeia das quatro às cinco à roda do prédio, com sua touca branca na cabeça e o bebé nos braços.

A criada também é grande. $E$ a touca é grande. Só o bebé é pequeno.

São os contrastes! (Cesariny 1985: 142)

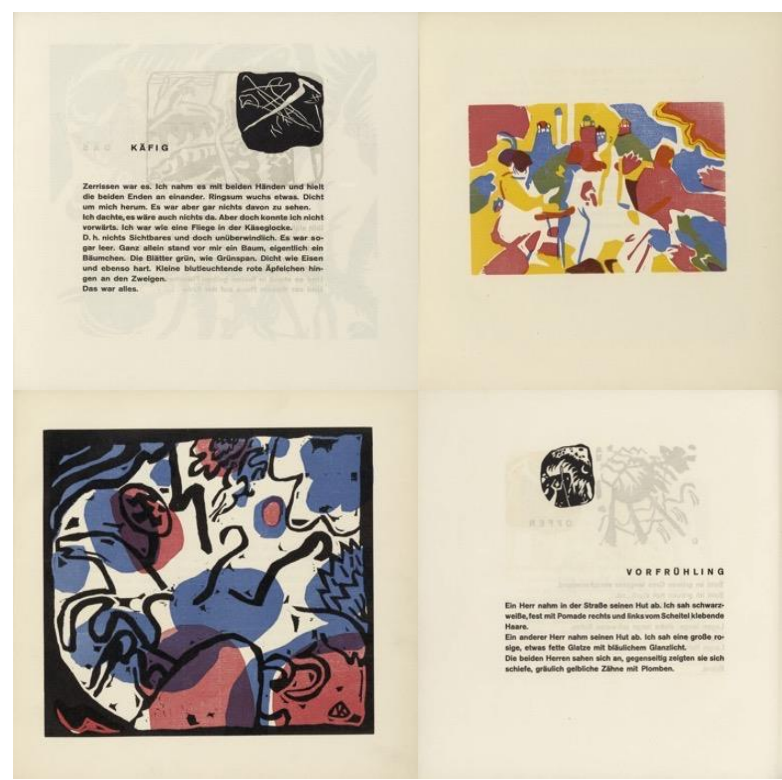

Figura 4 - Páginas de Klänge, Vasily Kandinsky (1912) 
Contudo, o interesse suscitado pela inclusão de "Os passeios" em uma obra tão utilizada pela crítica para justificar as práticas e as influências de Mário Cesariny se torna ainda maior quando se constata que o original em alemão não consta no livro de Kandinsky indicado, tampouco nas outras obras escritas do artista. O estranhamento causado pela ausência do poema original na publicação de 1912 vem somar-se ao fato de que não se tem notícia do conhecimento de alemão de Mário Cesariny, posto que as traduções por ele feitas são de originais em francês, em inglês e em espanhol, e que a primeira tradução integral do livro de Kandinsky viria a lume com a edição em francês de seus escritos apenas em 1970 isto é, dois anos após a publicação da tradução de Cesariny no Jornal de Letras e Artes, em abril de 1968. Como, então, ler uma tradução que não encontra o seu original? Seria possível que Cesariny teria inventado um texto de Kandinsky, tornando-se ele mesmo o outro artista por meio de uma apropriação de seus temas principais, sua dicção, suas cores? Isto é, teria ele criado a tal ponto a sua própria tradição que nela recolhe obras falsas?

A hipótese de que Cesariny teria se transformado em Kandinsky sob o pretexto de traduzi-lo não parece absurda, haja vista que um processo similar se dá com Fernando Pessoa, em 1989. Além de ser corroborada pelo caso de O Virgem Negra, a hipótese ganha força ao se observar que o jogo com a autoria de seus poemas já fora posto por Cesariny em diversos momentos, como em Nicolau Cansado Escritor (1961), livro no qual cria um poeta fictício, "Nicolau Cansado", que seria o autor dos poemas publicados, ficcionalizando também a existência de críticos e estudiosos da obra deste, como "Araruta Província" e "Maria Palhinha". Outro fator que contribui para reforçar a leitura de uma ficção autoral em "Os passeios" é a ausência, no espólio que se encontra no Centro Português do Surrealismo, na Fundação Cupertino de Miranda, de qualquer livro de Kandinsky, sendo o único documento referente ao autor de Klänge um recorte de revista com o artigo "Le cavalier bleu", de Will Grohmann, publicado em setembro de 1955 em L'Oeill, no 9. ${ }^{3}$ Ademais, a linguagem simples, a maneira de o eu lírico se dirigir a um interlocutor para com ele estabelecer um diálogo e as repetições de certas expressões dão a algumas passagens do poema um tom irônico que se encontra em diversos momentos da escrita de Cesariny. Assim, "Os passeios" poderia facilmente ser lido como um poema do artista português:

Impossível não reparar na grande chaminé que está no outro lado do grande campo amarelo dourado. 
Justamente: a chaminé aparece no extremo limite do grande campo amarelo dourado - no lado oposto ao grande prédio.

É uma coisa natural, sem enigma. [...]

É mais que natural.

O que é bocadinho inquietante, é que todos os dias, entre as quatro e as cinco horas precisas, um grande cavalo branco vem dar um passeio à volta da grande chaminé.

Mas, enfim, também é natural. O grande cavalo passeia em volta da grande chaminé.

Ora! Deixá-lo passear!

E a criada, que se passeie! [...]

Deus meu, não há nada mais natural!

Um tanto enigmático - pelo menos, para mim - é que a criada passeia todos os dias à roda do grande prédio não somente das quatro às cinco horas precisas, mas também da direita para a esquerda.

Mas... isto ainda podia admitir-se.

Por que não?

Verdadeiramente enigmático - pelo menos para mim - é que, simultaneamente - todos os dias das quatro às cinco horas - o grande cavalo branco anda às voltas da esquerda para a direita.

Ide, e vê-lo-eis.

Quase me esquecia de acrescentar que a dita criada é bonita. Muito bonita. Muito, muito, muito bonita.

E o cavalo também não está mal. (Cesariny 1985: 142-143)

Há algumas passagens de outros poemas de Klänge que parecem se repetir no texto que Cesariny teria traduzido. Assim, se, neste, lê-se a respeito de "um grande cavalo branco" que "todos os dias, entre as quatro e as cinco horas precisas, [...] vem dar um passeio à roda da grande chaminé" (Cesariny 1985: 142) e de uma criada que "passeia todos os dias à roda do grande prédio não somente das quatro às cinco horas precisas, mas também da direita para a esquerda" (idem: 142-143), num dos poemas publicados em 1912, intitulado "Nicht" ["Não"], lê-se sobre um "springender Mann" ["homem que pula"] que "in the flat, hard, dry ground [dug] a small very round depression and jumped over it without stopping every day from 4 o'clock to 5" ["no chão plano, duro, seco, cavou um buraco pequeno muito redondo e pulava sobre ele sem parar todos os dias das quatro às cinco horas"] (Kandinsky 1981: 53, tradução nossa). Há, também, outros poemas que se assemelham ao que foi traduzido, especialmente no que se refere ao uso de adjetivos como "grande", "pequeno" e "bonito", que caracterizam uma linguagem simples, próxima à fala infantil, bem como na escolha dos 
elementos que compõem a cena, haja vista que muitos são os cavalos, as mulheres de toucas, as chaminés e os campos que aparecem nos textos e nas gravuras de Klänge, além da repetição das cores-tema, branco e amarelo, bem como da reiteração que caracteriza, para Napier, um interesse especial de Kandinsky como poeta, traços que põem em foco os sons, as ressonâncias, das palavras, para além de seus significados.

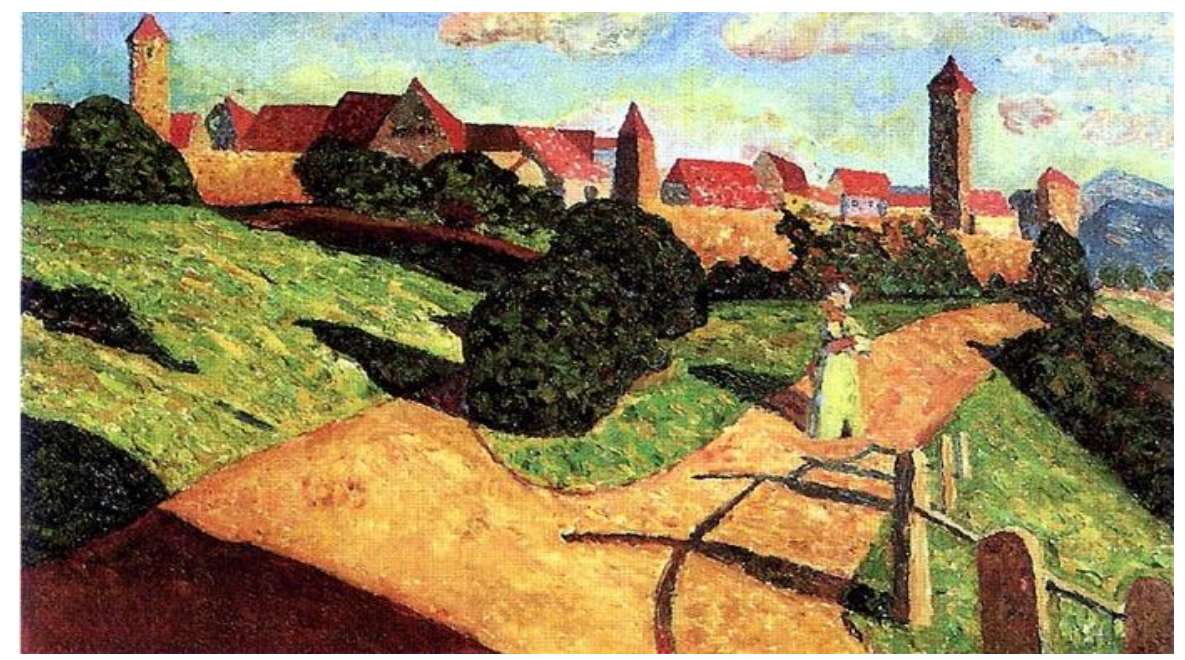

Figura 5 - Old Town II, Vasily Kandinsky (1902), óleo sobre tela, 52 x 78,5 cm

Seria possível, então, compreender o poema que Cesariny traduz como uma falsa tradução de um poema e uma efetiva transposição de alguns temas recorrentes nos poemas de Kandinsky, aliada a certo exercício ecfrástico de descrição de telas e gravuras. Nesse caminho interpretativo, pode-se perceber que algumas telas de Kandinsky estariam descritas em "Os passeios", como Old Town II (1902, figura 5), na qual uma mulher passeia de touca branca sob a luz do fim da tarde, ou obras já abstratas como Impression III (Concert) (1911, figura 6), na qual o amarelo dourado toma a maior parte da superfície, e Composition VIII (1923, figura 7), onde o espectador julga ser possível distinguir relógios, cavalos e chaminés.

Tomar o texto supostamente traduzido como um poema até então escondido de Mário Cesariny tem como consequência a percepção de que, no livro As Mãos na Água, a Cabeça no Mar, foi incluída a forma de discurso crítico mais recorrente em sua obra: aquela que se dá por meio da criação poética. Com "Os passeios", o diálogo com a produção alheia transitaria pelos caminhos diversos que o outro artista também percorreu, mesclando os poemas e a memória da leitura às obras plásticas e ao exercício do olhar. 


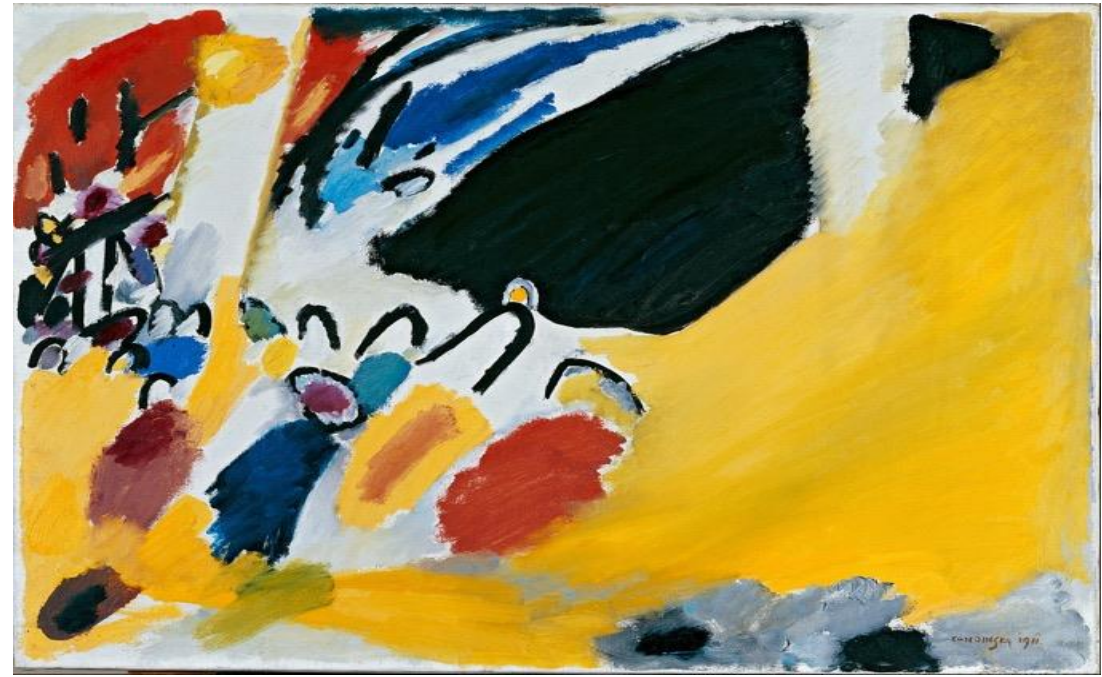

Figura 6 - Impression III (Concert), Vasily Kandinsky (1911), óleo sobre tela, 77,5 x $100 \mathrm{~cm}$

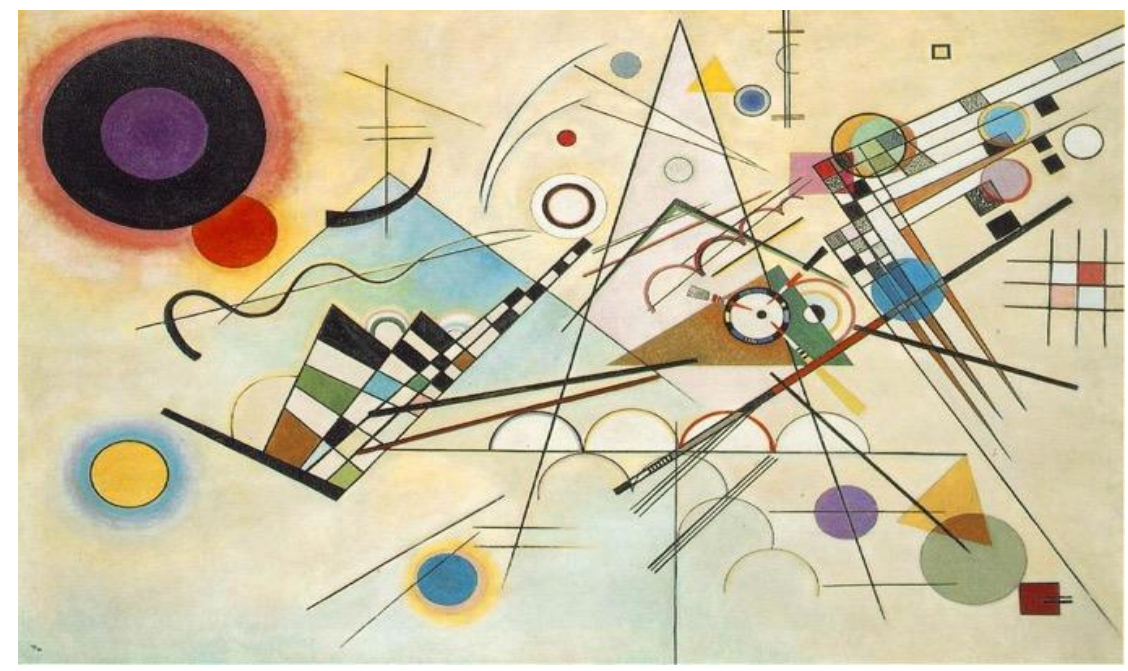

Figura 7 - Composition VIII, Vasily Kandinsky (1923), óleo sobre tela, 140 × 201 cm

Ao anunciar constantemente seus exercícios de leitura, Cesariny emerge como um poeta crítico - de si e de outrem -, fazendo com que a ligação entre a prática artística e a crítica de arte seja enfaticamente reafirmada, assumindo a criação poética como um espaço que se abre ao encontro com o outro. Tomá-lo como um artista crítico permite pô-lo em diálogo com Octavio Paz, para quem a literatura moderna se caracteriza pela "autonomia dos valores artísticos" (Paz 2013: 41) e pela consequente possibilidade de tomar-se a si mesma como objeto de interesse, introduzindo com isso as noções de autossuficiência e autorreferencialidade da arte. A poesia moderna traria, então, "a noção da crítica 'dentro' 
da criação poética" (ibidem). Nesse sentido, voltando-se sobre si mesma e tomando-se como seu próprio objeto de investigação, instaura uma simultaneidade entre a sua prática e a sua crítica, fazendo com que os poemas sejam a coincidência entre o fazer poético e a consciência que reflete acerca deste, numa dobra autocrítica.

No campo da poesia, recorrer a obras e poemas alheios pode ser percebido como uma maneira de definição de uma poética própria, sendo um modo tanto de ler a obra do outro quanto de encontrar o que é seu nele. Assim, os múltiplos diálogos que se encontram na obra de Cesariny podem ser tomados tanto como uma reflexão acerca da arte quanto como uma busca de si. Esse trabalho, se lança o autor a procurar pelo outro fora de sua obra, tem como campo de experimentação e estação de chegada a matéria bruta, a tela e a página em branco.

\section{Mário Cesariny, autor de "Os passeios"}

A aposta na confusão de informações e na possibilidade de pôr em contato, a um só tempo, todas as influências e experiências poderia ser uma definição da poética surrealista de Mário Cesariny. A pluralidade de diálogos que traz ao seio de sua obra certamente faz com que o seu leitor esteja sempre atento aos ecos de vozes alheias e aos jogos de leitura, arriscando-se, sem dúvida, a possíveis enganos. É assim que encontra, finalmente, o poema original de Vasily Kandinsky, em uma edição em italiano dos escritos do artista russo na qual se incluem suas peças de teatro e todos os seus poemas. "Les promenades" não foi publicado em 1912, em alemão no livro Klänge, mas foi escrito em 1939, em francês, língua que Mário Cesariny dominava tanto como tradutor quanto como poeta. Na organizada bibliografia da edição italiana Tutti gli scritti (1974) de Vasily Kandinsky, há referências a todas as obras utilizadas para a recolha dos textos que a compõem. Não há, contudo, nenhuma indicação a respeito da publicação original do poema, sendo incluído em uma seção intitulada, apenas, "Outros poemas".

Cesariny é então, de fato, o tradutor de "Os passeios". Mas, como sublinha Haroldo de Campos retomando Octavio Paz e Novalis em "Poesia e Modernidade: da morte da arte à constelação. O poema pós-utópico”, “[o] tradutor, como diz Novalis, é ‘o poeta do poeta', o poeta da poesia. A tradução - vista como prática de leitura reflexiva da tradição - permite 
recombinar a pluralidade dos passados possíveis e presentificá-la" (Campos 1997: 269). Nesse sentido, a tradução seria a maneira por meio da qual se é possível tornar-se mais o outro, num movimento em que a voz de um outro é chamada a ressoar em um poeta que se abre como um "condutor-isolador da corrente poética" (Cesariny 2004: 83), como reza a citação de Novalis frequentemente lembrada por Cesariny. Portanto, se a criação do seu outro é um ponto alto na fundação de sua própria tradição, a tradução seria o ponto máximo da relação entre crítica e poesia.

Há algo de borgiano na leitura de uma obra como a de Mário Cesariny. É inevitável a comparação do percurso de leitura de "Os passeios" com "Pierre Menard, autor do Quixote", de Jorge Luis Borges, no qual um narrador estuda os três capítulos do D. Quixote que Pierre Menard teria escrito - exatamente iguais aos publicados por Cervantes - sem que tivesse recorrido à cópia das palavras do autor original. O narrador afirma que, com sua empreitada, "Menard (talvez sem querê-lo) enriqueceu, mediante uma técnica nova, a arte fixa e rudimentar da leitura: a técnica do anacronismo deliberado e das atribuições errôneas" (Borges 1999: s.p.). Algo similar fez Cesariny ao se tornar autor de "Os passeios" durante o tempo que nos dedicamos a esta pesquisa. Se o narrador de Borges compara o "estilo" da escrita a partir dos autores dos capítulos, afirmando que Menard tem um "estilo arcaizante [...] - no fundo, estrangeiro - [que] padece de alguma afetação", e que Cervantes "emprega com desenvoltura o espanhol corrente de sua época" (idem: s.p.), seria possível defender que, como autor de "Os passeios", Cesariny emprega uma dicção algo afetada, mas sem dúvida muito irônica, ao passo que Kandinsky mostra com desenvoltura as possibilidades de associação entre palavra e imagem, ao pôr em movimento, por meio da narração, quadros que parecem imóveis, numa espécie de écfrase de sua própria obra. 


\section{NOTAS}

\footnotetext{
1 No somatório de 251 poemas, não foram contabilizados os de O Virgem Negra, pois, ainda que seja reproduzido em Poesia (2017), todo o livro remete à obra de Fernando Pessoa.

${ }^{2}$ Todas as traduções de Napier são nossas.

${ }^{3}$ Pesquisa feita em Portugal entre maio e junho de 2016 com os documentos presentes no espólio de Mário Cesariny, no Centro Português do Surrealismo, Fundação Cupertino de Miranda.
}

\section{Bibliografia}

Borges, Jorge Luis (1999), "Pierre Menard, autor do Quixote", Obras completas de Jorge Luis Borges, vol. 1, São Paulo, Globo, s.p.

Breton, André (1924), "Manifesto do Surrealismo", <http://joaocamillopenna.files. wordpress.com/2012/10/breton-manifesto-do-surrealismo. pdf> (último acesso em 10/06/2014).

Campos, Haroldo de (1997), "Poesia e Modernidade: da morte da arte à constelação. O poema pós-utópico", O Arco-íris Branco, Rio de Janeiro, Imago, 243-269.

Cesariny, Mário (1966), A Intervenção Surrealista, Lisboa, Assírio \& Alvim.

-- (1985) As Mãos na Água, a Cabeça no Mar, Lisboa, Assírio \& Alvim.

-- (2004) Pena Capital, Lisboa, Assírio \& Alvim.

-- (2008) Manual de Prestidigitação, Lisboa, Assírio \& Alvim.

-- (2017) Poesia, edição, prefácio e notas de Perfecto E. Cuadrado, Lisboa, Assírio \& Alvim. 
Gomes, Julia (2016), Fernando Pessoa revisited. Uma leitura de O Virgem Negra, de Mário Cesariny, dissertação de mestrado apresentada à Faculdade de Letras da UFRJ, Rio de Janeiro.

Gusmão, Manuel (2010), "Entre nós e as palavras (Mário Cesariny)", Tatuagem \& Palimpsesto, Lisboa, Assírio \& Alvim, 388-406.

Kandinsky, Vasily (1912), Klänge. Munique. < https://www.moma.org/collection/ works/illustratedbooks/ 26560?locale=pt > (último acesso 15/10/2017).

-- (1974) Tutti gli Scritti 2. Dello spirituale nell'arte, scritti critici e autobiografici, teatro, poesie, Milano, Giangiacomo Feltrinelli.

-- (1981) Sounds. Translated and with an introduction by Elisabeth R. Napier, New Heaven and London, Yale University.

Napier, Elizabeth R. (1981), "Introduction". In: Sounds. Translated and with an introduction by Elisabeth R. Napier, New Heaven and London, Yale University, 1-11.

Paz, Octavio (1982), O Arco e a Lira, tradução de Olga Savary, Rio de Janeiro, Nova Fronteira, 2a edição.

-- (2013) Os Filhos do Barro. Do romantismo à vanguarda, tradução de Ari Roitman e Paulina Wacht, São Paulo, CosacNaify.

Pessoa, Fernando (1985), Obra Poética. Em um volume, Rio de Janeiro, Nova Aguilar. 
Maria Silva Prado Lessa é mestra e doutoranda do Programa de Pós-Graduação em Letras Vernáculas da Universidade Federal do Rio de Janeiro. Defendeu, em 2017, a dissertação de Mestrado "O poema como palco: algumas cenas da escrita de Mário Cesariny", em que explorou o modo como os poemas do surrealista declaram e expõem seus processos de desenvolvimento por meio da apresentação de um ator responsável pelos papéis de autor e leitor. Atualmente, desenvolve a pesquisa "O autoractor: Mário Cesariny e a autografia", em que se volta para manifestação autoral na obra poética e plástica do artista. Sua produção acadêmica se concentra, principalmente, nos estudos de poesia portuguesa moderna e contemporânea. 